\title{
Chemotaxonomical Aspects of Lower Cretaceous Amber from Recôncavo Basin, Brazil
}

\author{
Ricardo Pereira, ${ }^{*, a}$ Ismar S. Carvalho, ${ }^{b}$ Antonio Carlos S. Fernandes ${ }^{c}$ and Débora A. Azevedo*,a \\ ${ }^{a}$ Instituto de Química, Universidade Federal do Rio de Janeiro, 21941-909 Rio de Janeiro-RJ, Brazil \\ ${ }^{b}$ Instituto de Geociências, Universidade Federal do Rio de Janeiro, 21910-200 Rio de Janeiro-RJ, Brazil \\ 'Departamento de Geologia e Paleontologia, Museu Nacional, Universidade Federal do Rio de Janeiro, \\ Quinta da Boa Vista, s/n, 20940-040 Rio de Janeiro-RJ, Brazil
}

\begin{abstract}
A composição química de amostras de âmbar provenientes da Bacia do Recôncavo (Salvador, Bahia), datadas do Cretáceo Inferior, foi determinada por meio de CG-EM para caracterização das suas possíveis fontes botânicas. Os principais compostos identificados foram diterpenoides, tais como abietano, deidroabietano, tetraidroreteno, deidroabietol, ácido deidroabiético, ferruginol e sugiol. Outras classes de diterpenoides ou triterpenos não foram detectados. A composição dos extratos e os dados quimiotaxonômicos permitiram relacionar as amostras com coníferas das famílias Podocarpaceae ou Cheirolepidiaceae devido à detecção do ferruginol, um biomarcador específico para estas famílias. Desta forma, os dados concernentes aos âmbares da Bacia do Recôncavo forneceram informações quanto à presença de uma flora resinífera na Formação Maracangalha, quando da deposição de seus sedimentos durante o Cretáceo Inferior.
\end{abstract}

The chemical composition of Lower Cretaceous amber samples from Recôncavo Basin (Salvador, Bahia) was performed by GC-MS to characterize possible botanical sources. The compounds identified were hydrocarbonic and polar diterpenoids, such as abietane, dehydroabietane, tetrahydroretene, dehydroabietol, dehydroabietic acid, ferruginol and sugiol. Other diterpenoid classes were not detected as well as triterpenoids. The composition of the extracts and chemosystematic data allows relating the samples to conifers of Podocarpaceae or Cheirolepidiaceae families due to detection of ferruginol, a specific biomarker to these families. The data concerning Cretaceous amber in the Recôncavo Basin provided information concerning the presence of a resinous flora in the Maracangalha Formation sediments during the Lower Cretaceous.

Keywords: cretaceous amber, chemotaxonomy, diterpenoids, conifers, Recôncavo Basin

\section{Introduction}

Amber is the fossil form of plant resins occurring in terrestrial sediments throughout the geologic record since the Carboniferous ${ }^{1}$ and is relatively frequent in Cenozoic sediments. They are common sedimentary constituents in many areas and occur in large quantity in some deposits (e.g., around the Baltic region and in the Dominican Republic). ${ }^{2}$ The Cretaceous amber occurrences have been studied in several localities. Although the earliest Cretaceous amber-bearing deposits are localized in the Levantine amber belt (Jordan, Lebanon and Israel), the most numerous occurrences are from Northern hemisphere, mainly in USA (Atlantic Coastal Plain), Canada and

*e-mail: ricardopereira@iq.ufrj.br, debora@iq.ufrj.br
Europe. ${ }^{3}$ Amber deposits from Upper Cretaceous were reported to USA, Canada, Russia and Myanmar (Burma) and samples of this age is not known in the South hemisphere. ${ }^{4}$ Regarding specifically Lower Cretaceous, significant amber deposits occur in England, Spain, France, Middle Eastern (Levantine amber belt), Africa and Brazil.

Spectroscopic techniques have been applied to the structural and molecular elucidation of amber samples, such as solid state Fourier transform infrared (FT-IR), solid state ${ }^{13} \mathrm{C}$ nuclear magnetic resonance $\left({ }^{13} \mathrm{C}\right.$ NMR), gas chromatography-mass spectrometry (GC-MS) and pyrolysis-gas chromatography-mass spectrometry (Py-GC-MS) ${ }^{3-9}$ Among these techniques Py-GC-MS and GC-MS are noteworthy because allows individual components of amber extracts to be separated and provides mass spectra for structural and molecular elucidation. The 
terpenoids are common resin constituents and can be used as chemotaxonomic markers to elucidated the botanical origin of ambers, as well determining information related to diagenetic alterations. ${ }^{3,9}$

Analysis of Lower Cretaceous amber from southern England (Isle of Wight - Barremian) by Py-GC-MS indicates a terpene composition dominated by abietane and labdane-type diterpenes, in according to some species of the family Pinaceae. ${ }^{5}$ However, the authors could not exclude a possible botanical source linked to Cheirolepidiaceae, considering the presence of a large amount of micro and macrofossils from the mentioned family in the sediments where the amber samples were collected. ${ }^{5}$ Later, other authors have also proposed this family as a possible botanical source for amber samples based in paleontological evidences. ${ }^{8,9}$

Unfortunately, there were no geochemical evidences that could associate specific terpenoid classes to the Cheirolepidiaceae family. Recently, based on chemistry and pollen evidence, Menor-Salván et al. ${ }^{7}$ proposed new chemotaxonomical data about the paleobotanical origin of spanish ambers from Lower Cretaceous sediments of the Basque-Cantabrian Basin. The terpenoid composition of the studied amber samples and the possibility of obtaining molecular data from Frenelopsis leaves (Cheirolepidiaceae family, extinct since the end of Cretaceous period) associated with the fossil resins analyzed in the mentioned paper indicated a paleobotanical origin related to the Cheirolepidiaceae family. The work demonstrated that phenolic terpenoids of abietane class are chemotaxonomic markers to this extinct family.
Amber occurrences in cretaceous sediments from the South hemisphere are restricted to Africa and Brazil essentially. The african ambers are from Valanginian of the Kirkwood Formation (South Africa) with possible connection to Araucariaceae, Podocarpaceae or Cheirolepidiaceae families. ${ }^{8}$ Amber samples in Brazil were obtained in Lower Cretaceous sediments from Amazonas, Araripe and Recôncavo basins. ${ }^{9,10}$ GC-MS information regarding the chemical composition of samples collected in these basins is complex, including some mono and sesquiterpenes, abietanes and norabietanes, labdanes, pimaranes, isopimaranes, kauranes and phyllocladanes. The geochemical data of Brazilian ambers pointed to several possible botanical origins, such as Cupressaceae, Araucariaceae or Podocarpaceae families. ${ }^{9,10}$ For the Recôncavo ambers, considering the presence of kauranes and phyllocladanes, almost certainly the biological affinity is Araucariaceae or Podocarpaceae families. ${ }^{9}$ The Table 1 summarizes some of the worldwide amber occurrences in Lower Cretaceous sediments, showing the proposed botanical affinities.

In the present paper, the extracts of three new Brazilian amber samples from Recôncavo Basin were analyzed using GC-MS and their chemical composition characterized aiming the evaluation of possible botanical origins. The results obtained were compared with that reported before to other samples of the same stratum ${ }^{9}$ and other brazilian ambers with analogous biomarker composition. ${ }^{10}$ This work provides new data concerning the molecular composition of Brazilian fossil resins, mainly the Recôncavo ambers, based in new information reported about chemotaxonomic aspects

Table 1. Inferred botanical affinities of some Lower Cretaceous amber deposits

\begin{tabular}{|c|c|c|}
\hline Age/Locality & Inferred Botanical Affinity & Reference \\
\hline Albian Myanmar & Possibly Araucariaceae or Cupressaceae; based on associated palynomorphs & 11 \\
\hline Albian France & Araucariaceae; based on associated plant fossils & 6 \\
\hline Albian Spain & Araucariaceae; based on FTIR, GC-MS and associated pollen & 12 \\
\hline Albian Spain & Cheirolepidiaceae; based on CG-MS and associated plant fossils & 7 \\
\hline Albian Brazil (Amazonas Basin) & Possibly Araucariaceae, Cupressaceae or Cheirolepidiaceae; based on GC-MS and associated pollen & 9 \\
\hline Aptian Brazil (Araripe Basin) & Araucariaceae; based on FTIR and associated plant fossils & 13 \\
\hline Aptian Brazil (Araripe Basin) & $\begin{array}{l}\text { Possibly Araucariaceae, Cupressaceae or Cheirolepidiaceae; based on GC-MS and associated pollen } \\
\text { and plant fossils }\end{array}$ & 9 \\
\hline Aptian Brazil (Araripe Basin) & Possibly Araucariaceae or Podocarpaceae; based on GC-MS, associated pollen and plant fossils & 10 \\
\hline Aptian-Albian Spain & Araucariaceae; based on FTIR, GC-MS and associated pollen and plant fossils & 6 \\
\hline Barremian Lebanon & Araucariaceae; based on GC-MS and plant fossils & 14 \\
\hline Hauterivian-Valanginian Israel & Araucariaceae; based on GC-MS and plant fossils & 14 \\
\hline Valanginian South Africa & Araucariaceae or Cheirolepidiaceae; based on associated plant fossils and pollen & 8 \\
\hline $\begin{array}{l}\text { Berriasian-Barremian Brazil } \\
\text { (Recôncavo Basin) }\end{array}$ & Possibly Araucariaceae, Podocarpaceae or Cupressaceae; based on GC-MS & 9 \\
\hline
\end{tabular}


of coniferophytes. ${ }^{7}$ In this way, the research about Brazilian Cretaceous amber has a great importance to increase the knowledge regarding the chemical composition of fossil resins in deposits from the South hemisphere, particularly South America.

\section{Experimental}

\section{Geological setting and sampling}

Three amber samples (Figure 1) were collected on Ilha dos Frades (Frades Island) at Recôncavo Basin, Maracangalha Formation (Caruaçu Member), Salvador, state of Bahia, Brazil. The depositional environment consists in lacustrine sandstones of Lower Cretaceous age (Neocomian, between 130 and 145 million years ago). ${ }^{15}$ All samples were taken as angular or subspherical clasts with around $1.0 \mathrm{~cm}$ in diameter and color from yellow to reddish brown. The Recôncavo amber clasts were found associated with carbonized plant fragments.

The Maracangalha Formation belongs to the rift phase of the Recôncavo Basin, northeastern Brazil. It was deposited during the first fragmentation stages of the Gondwana supercontinent in the Early Cretaceous and consists of light to dark-greenish shales and sandstones of Early Cretaceous age (Rio da Serra and Aratu local

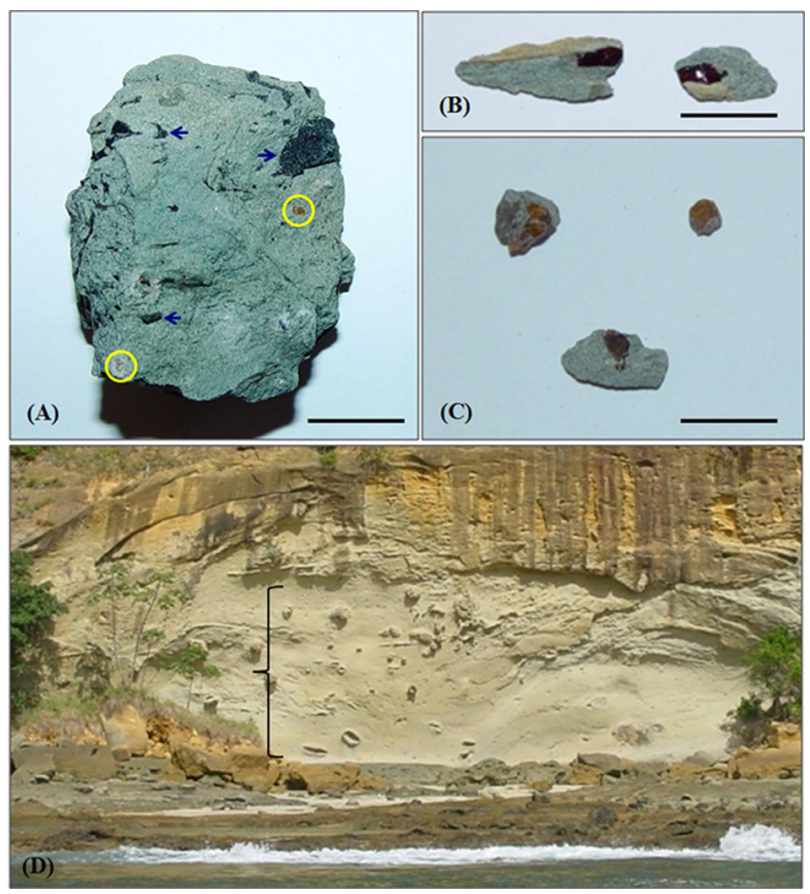

Figure 1. Lower Cretaceous amber from Recôncavo Basin, Brazil. Scale bars represent $1.0 \mathrm{~cm}$. (A) Sample 1: Sandstone with amber clasts (circles) and carbonized plant fragments (arrows); (B) and (C) Samples 2 and 3: Amber clasts isolated from the sediments; (D) Photography of Maracangalha Formation outcrop where amber samples were collected. The amber level is indicated by bracket. stages). The deposits of Maracangalha Formation have been interpreted as related to subaqueous gravity flows and mass movements in the context of a lacustrine environment developed during the rift process of Neocomian times. They are interpreted as progradation of deltaic fronts triggered by slumps and slides movements due turbidity currents related to a great tectonic instability. ${ }^{15,16}$

\section{Extraction, derivatization and GC-MS analyses}

The powdered samples $(50 \mathrm{mg})$ were sonicated and extracted three times with $5 \mathrm{~mL}$ of $\mathrm{CH}_{2} \mathrm{Cl}_{2}: \mathrm{CH}_{3} \mathrm{OH}(1: 1$; $\mathrm{v}: \mathrm{v})$ in each extraction. The combined extracts were evaporated with a rotary evaporator, transferred prior to drying to a vial and the residual solvent was removed under $\mathrm{N}_{2}$. Aliquots of the total extract were derivatized using reaction with $\mathrm{N}, \mathrm{O}-$ bis(trimethylsilyl)trifluoroacetamide (BSTFA) for $30 \mathrm{~min}$ at $60{ }^{\circ} \mathrm{C}$. GC-MS analyses of the underivatized and derivatized extracts of the three samples were performed on an Agilent Technologies 5890 gas chromatograph coupled to a 5973 mass selective detector. Separation was achieved with a DB5 fused silica column ( $30 \mathrm{~m} \times 0.25 \mathrm{~mm}$ i.d. $\times 0.25 \mu \mathrm{m}$ film thickness). The GC oven operating conditions were $60-300{ }^{\circ} \mathrm{C}$ (held $10 \mathrm{~min}$ ) at $6{ }^{\circ} \mathrm{C} \mathrm{min}{ }^{-1}$. Helium was used as carrier gas and samples were injected in splitless mode with injector temperature at $290{ }^{\circ} \mathrm{C}$. The mass spectrometer was operated in the full scan mode from $\mathrm{m} / \mathrm{z}$ 50-500 and with electron impact ionization $(70 \mathrm{eV})$. Individual compounds were identified by comparison of mass spectra with those of standards, and with literature ${ }^{17,20,22,24}$ and electronic library data (NIST Mass Spectral Database). Relative retention times and interpretation of MS fragmentation patterns were used.

\section{Results and Discussion}

\section{Molecular composition of the extracts}

The total extracts of the amber samples contain mainly diterpenoids and irrelevant amounts of alkylnaphthalenes and alkylhydronaphthalenes. The most important diterpenoids detected are from regular abietane skeletons, and additionally some polar abietanes and norabietanes. The compounds identified in the extracts are given in Table 2, along with their occurrence in the samples studied here and in the Recôncavo amber reported previously. ${ }^{9}$ Enlarged section of the total ion chromatograms (19-30 $\mathrm{min})$ are presented in Figure 2. Chemical structures of compounds detected in Recôncavo ambers are given in Figure 3.

Regular and phenolic/keto-phenolic abietanes, as well some norabietanes, are the only diterpenoids in the fossil 
Table 2. Compounds identified in total extracts of Recôncavo ambers

\begin{tabular}{|c|c|c|c|c|c|c|c|c|}
\hline \multirow[b]{2}{*}{ No. } & \multirow[b]{2}{*}{ Compound name } & \multirow[b]{2}{*}{ Composition } & \multirow[b]{2}{*}{ MW } & \multicolumn{4}{|c|}{ Compound occurrence in the sample ${ }^{\mathrm{a}}$} & \multirow[b]{2}{*}{ Reference } \\
\hline & & & & $\begin{array}{c}\text { Sample } \\
01\end{array}$ & $\begin{array}{c}\text { Sample } \\
02\end{array}$ & $\begin{array}{c}\text { Sample } \\
03\end{array}$ & $\begin{array}{c}\text { Previous } \\
\text { sample }^{\mathrm{b}}\end{array}$ & \\
\hline \multicolumn{9}{|c|}{ Sesquiterpenoids } \\
\hline 1 & Calamene & $\mathrm{C}_{15} \mathrm{H}_{22}$ & 202 & ND & ND & ND & $P$ & S, 20,17 \\
\hline \multicolumn{9}{|c|}{ Diterpenoids } \\
\hline \multicolumn{9}{|c|}{ Regular Abietanes and Norabietanes } \\
\hline 2 & $16,17,19$-Trisnorabieta-8,11,13-triene & $\mathrm{C}_{17} \mathrm{H}_{24}$ & 228 & ND & ND & $\mathrm{P}$ & $\mathrm{P}$ & 17 \\
\hline 3 & $16,17,18$-Trisnorabieta-8,11,13-triene & $\mathrm{C}_{17} \mathrm{H}_{24}$ & 228 & $\mathrm{P}$ & $\mathrm{P}$ & $\mathrm{P}$ & $\mathrm{P}$ & 17 \\
\hline 4 & 7-Oxo-15-norpodocarpane & $\mathrm{C}_{17} \mathrm{H}_{24}$ & 228 & ND & ND & ND & $\mathrm{P}$ & S, 17 \\
\hline 5 & 1,2,3,4-Tetrahydroretene & $\mathrm{C}_{18} \mathrm{H}_{22}$ & 238 & $\mathrm{P}$ & $\mathrm{P}$ & $\mathrm{P}$ & ND & 22 \\
\hline 6 & 16,17-Bisnordehydroabietane & $\mathrm{C}_{18} \mathrm{H}_{26}$ & 242 & ND & ND & ND & $\mathrm{P}$ & 17 \\
\hline 7 & 7-Oxo-16,17,19(or 16,17,18)-trisnorabieta-8,11,13-triene & $\mathrm{C}_{17} \mathrm{H}_{22} \mathrm{O}$ & 242 & ND & ND & ND & $\mathrm{P}$ & S, 17 \\
\hline 8 & $16,17,19$ (or 16,17,18)-Trisnorabiet-8-en-7-one & $\mathrm{C}_{17} \mathrm{H}_{26} \mathrm{O}$ & 246 & ND & ND & ND & $\mathrm{P}$ & I \\
\hline 9 & 14-Methyl-16,17-bisnordehydroabietane & $\mathrm{C}_{19} \mathrm{H}_{28}$ & 256 & ND & ND & ND & $\mathrm{P}$ & I \\
\hline 10 & 18-Norabieta-8,11,13-triene & $\mathrm{C}_{19} \mathrm{H}_{28}$ & 256 & $\mathrm{P}$ & $\mathrm{P}$ & $\mathrm{P}$ & ND & 20,22 \\
\hline 11 & 19-Norabieta-8,11,13-triene & $\mathrm{C}_{19} \mathrm{H}_{28}$ & 256 & $\mathrm{P}$ & $\mathrm{P}$ & $\mathrm{P}$ & ND & 20,22 \\
\hline 12 & 10-Norabieta-8,11,13-triene & $\mathrm{C}_{19} \mathrm{H}_{28}$ & 256 & $\mathrm{P}$ & $\mathrm{P}$ & $\mathrm{P}$ & ND & $20,22, \mathrm{I}$ \\
\hline 13 & Norabietane & $\mathrm{C}_{19} \mathrm{H}_{34}$ & 262 & $\mathrm{P}$ & $\mathrm{P}$ & $\mathrm{P}$ & ND & 22 \\
\hline 14 & Abietane & $\mathrm{C}_{20} \mathrm{H}_{36}$ & 276 & $\mathrm{P}$ & $\mathrm{P}$ & $\mathrm{P}$ & ND & 22 \\
\hline 15 & Dehydroabietane & $\mathrm{C}_{20} \mathrm{H}_{30}$ & 270 & $\mathrm{P}$ & $\mathrm{P}$ & $\mathrm{P}$ & $\mathrm{P}$ & S, Nist \\
\hline 16 & Abieta-7,13-diene & $\mathrm{C}_{20} \mathrm{H}_{32}$ & 272 & $\mathrm{P}$ & ND & $\mathrm{P}$ & ND & 20 \\
\hline 17 & 16,17-Bisnorcallitrisic acid & $\mathrm{C}_{18} \mathrm{H}_{24} \mathrm{O}_{2}$ & 272 & ND & ND & ND & $\mathrm{P}$ & $24, \mathrm{I}$ \\
\hline 18 & Dehydroabietal & $\mathrm{C}_{20} \mathrm{H}_{28} \mathrm{O}$ & 284 & $\mathrm{P}$ & $\mathrm{P}$ & $\mathrm{P}$ & ND & Nist, I \\
\hline 19 & 16,17-Bisnordehydroabietic acid & $\mathrm{C}_{18} \mathrm{H}_{24} \mathrm{O}_{2}$ & 272 & ND & ND & ND & $\mathrm{P}$ & $24, \mathrm{I}$ \\
\hline 20 & Ferruginol & $\mathrm{C}_{20} \mathrm{H}_{30} \mathrm{O}$ & 286 & $\mathrm{P}$ & $\mathrm{P}$ & $\mathrm{P}$ & ND & Nist, I \\
\hline 21 & Dehydroabietol & $\mathrm{C}_{20} \mathrm{H}_{30} \mathrm{O}$ & 286 & $\mathrm{P}$ & $\mathrm{P}$ & $\mathrm{P}$ & ND & Nist, I \\
\hline 22 & Dehydroabietic acid & $\mathrm{C}_{20} \mathrm{H}_{28} \mathrm{O}_{2}$ & 300 & $\mathrm{P}$ & $\mathrm{P}$ & $P$ & ND & Nist, 20 \\
\hline 23 & Sugiol & $\mathrm{C}_{20} \mathrm{H}_{28} \mathrm{O}_{2}$ & 300 & ND & ND & $\mathrm{P}$ & ND & Nist, I \\
\hline 24 & Abiet-8-en-18-oic acid & $\mathrm{C}_{20} \mathrm{H}_{32} \mathrm{O}_{2}$ & 304 & ND & ND & $\mathrm{P}$ & ND & Nist, I \\
\hline 25 & Z(or E)-14,15-Bisnorlabda-8(20),12-dien-18-oic acid & $\mathrm{C}_{18} \mathrm{H}_{28} \mathrm{O}_{2}$ & 276 & ND & ND & ND & $\mathrm{P}$ & $25, \mathrm{I}$ \\
\hline 26 & Isopimar-8-en-18-oic acid & $\mathrm{C}_{20} \mathrm{H}_{32} \mathrm{O}_{2}$ & 304 & ND & ND & ND & $\mathrm{P}$ & 17 \\
\hline \multicolumn{9}{|c|}{ Kauranes and phyllocladanes } \\
\hline 27 & $\alpha-$ Phyllocladane & $\mathrm{C}_{20} \mathrm{H}_{34}$ & 274 & ND & ND & ND & $\mathrm{P}$ & $\mathrm{S}, 21$ \\
\hline 28 & Kaur-16-en-19-ol & $\mathrm{C}_{20} \mathrm{H}_{32} \mathrm{O}$ & 288 & ND & ND & ND & $\mathrm{P}$ & Nist \\
\hline 29 & Kauran-13-ol & $\mathrm{C}_{20} \mathrm{H}_{34} \mathrm{O}$ & 290 & ND & ND & ND & $\mathrm{P}$ & Nist \\
\hline \multicolumn{9}{|c|}{ Other compounds } \\
\hline 30 & Butyltrimethylbenzene & $\mathrm{C}_{13} \mathrm{H}_{20}$ & 176 & ND & ND & ND & $P$ & $26, \mathrm{I}$ \\
\hline 31 & 1,1,5,6-Tetramethyl-5,6-dehydrodecalin & $\mathrm{C}_{14} \mathrm{H}_{24}$ & 192 & ND & ND & ND & $\mathrm{P}$ & 5 \\
\hline 32 & 1,4a,5,6-Tetramethyldecalin & $\mathrm{C}_{14} \mathrm{H}_{26}$ & 194 & ND & ND & ND & $\mathrm{P}$ & I \\
\hline 33 & 1,1,4a-Trimethyl-6-oxo-7,8-dehydrodecalin & $\mathrm{C}_{13} \mathrm{H}_{20} \mathrm{O}$ & 192 & ND & ND & ND & $\mathrm{P}$ & $\mathrm{I}$ \\
\hline 34 & 1,1,5,6-Tetramethyl-2,3-dehydrodecalin & $\mathrm{C}_{14} \mathrm{H}_{24}$ & 192 & ND & ND & ND & $\mathrm{P}$ & $5, \mathrm{I}$ \\
\hline 35 & 1,1,5,6-Tetramethyl-8,8a-dehydrodecalin & $\mathrm{C}_{14} \mathrm{H}_{24}$ & 192 & ND & ND & ND & $P$ & $5, \mathrm{I}$ \\
\hline 36 & Ionene & $\mathrm{C}_{13} \mathrm{H}_{18}$ & 174 & $\mathrm{P}$ & $\mathrm{P}$ & $\mathrm{P}$ & $\mathrm{P}$ & $19,22,23$ \\
\hline 37 & Dimethylnaphthalene & $\mathrm{C}_{12} \mathrm{H}_{12}$ & 156 & $\mathrm{P}$ & ND & $\mathrm{P}$ & $\mathrm{P}$ & Nist, 22 \\
\hline 38 & Dimethylhexylbenzene & $\mathrm{C}_{14} \mathrm{H}_{22}$ & 190 & ND & ND & ND & $P$ & I \\
\hline 39 & Tetramethylbutylbenzene & $\mathrm{C}_{14} \mathrm{H}_{22}$ & 190 & $\mathrm{P}$ & $\mathrm{P}$ & $\mathrm{P}$ & $\mathrm{P}$ & 17 \\
\hline 40 & Methylionene & $\mathrm{C}_{14} \mathrm{H}_{20}$ & 188 & ND & ND & ND & $P$ & 17 \\
\hline 41 & Dimethylheptylbenzene & $\mathrm{C}_{15} \mathrm{H}_{34}$ & 204 & ND & ND & ND & $\mathrm{P}$ & 26 \\
\hline 42 & Trimethylhexylbenzene & $\mathrm{C}_{15} \mathrm{H}_{34}$ & 204 & ND & ND & ND & $\mathrm{P}$ & 26 \\
\hline 43 & Trimethylnaphthalene & $\mathrm{C}_{13} \mathrm{H}_{14}$ & 170 & $\mathrm{P}$ & $\mathrm{P}$ & $\mathrm{P}$ & $\mathrm{P}$ & Nist, 22 \\
\hline
\end{tabular}

a Compound occurrence in the sample: $\mathrm{P}=$ present, $\mathrm{ND}=$ not detected. Compound numbers refer to Figure 2 and Figure 3. ${ }^{\mathrm{b}}$ Molecular data of Recôncavo amber described in our previous paper. ${ }^{8}{ }^{\circ}$ Comparison of mass spectra with standard (S), electronic libraries (Nist2005), literature data and interpretation (I) of mass spectrometric fragmentation patterns. 


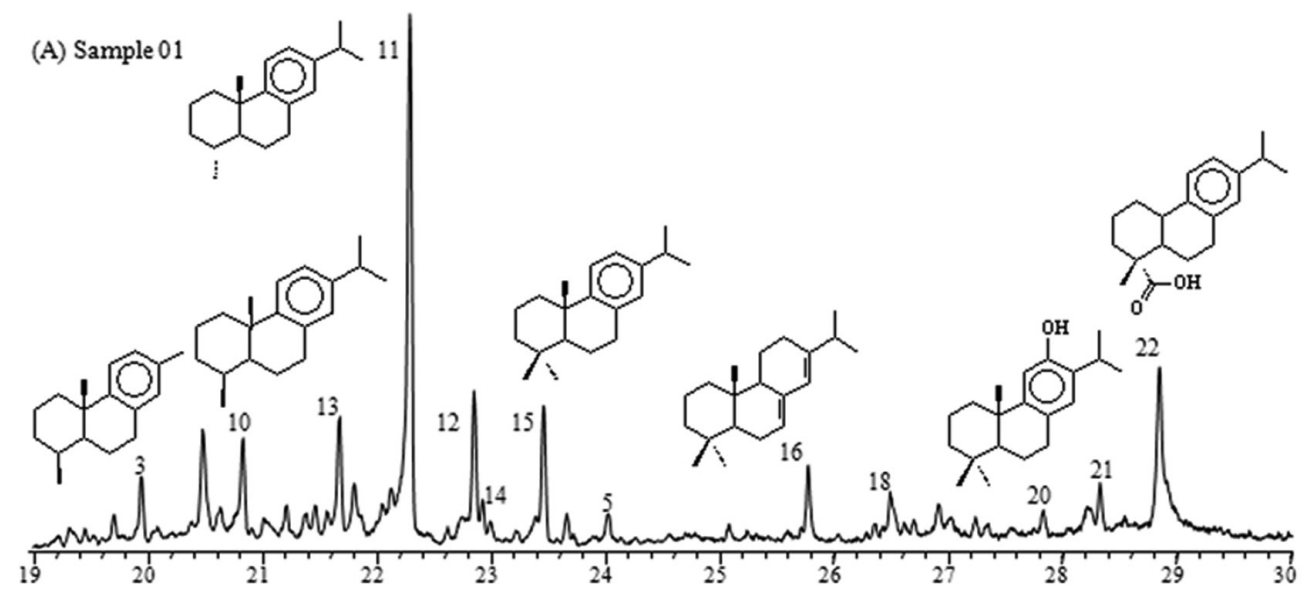

(B) Sample 02

11

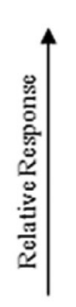



(C) Sample 03

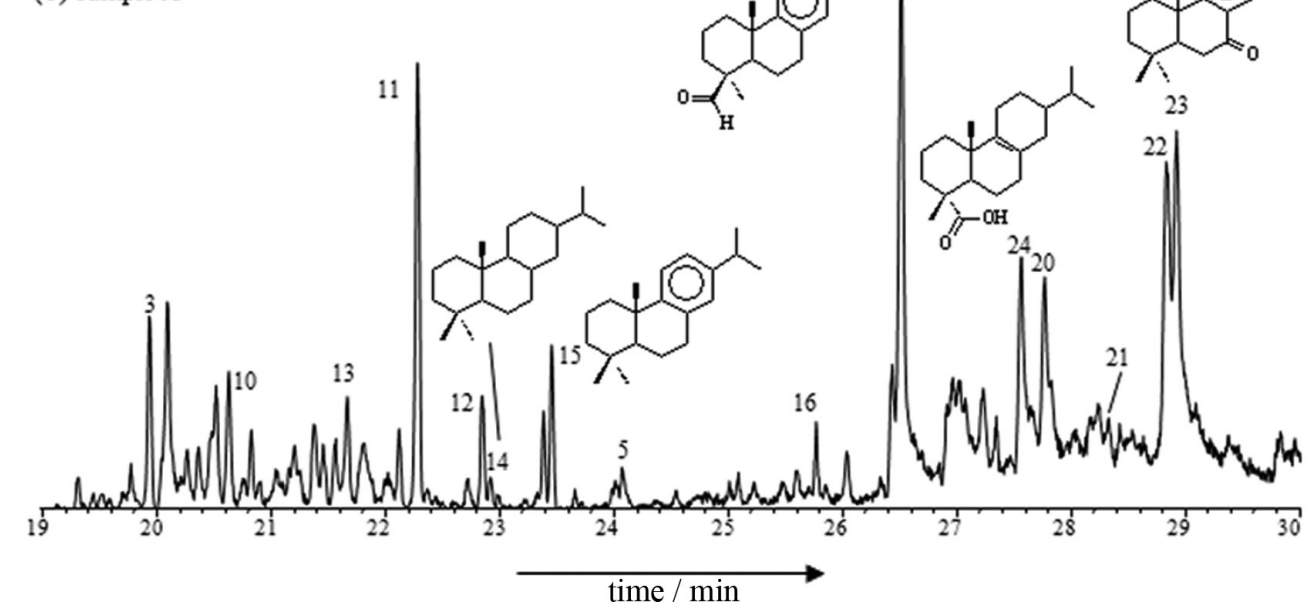

Figure 2. GC-MS of the Recôncavo Basin amber extracts, showing enlarged section of the total ion current trace (19-30 min): (A) sample 01; (B) sample 02; (C) sample 03. Peak numbers refer to Table 2 and Figure 3.

resin extracts analyzed. Hydrocarbons are exemplified by 16,17,18-trisnorabieta-8,11,13-triene ( 3 , numbers refer to Table 2, Figure 2 and Figure 3), 1,2,3,4-tetrahydroretene (5), 18-norabieta-8,11,13-triene (10), norabietane (13), abietane (14), dehydroabietane (15), and abieta-7,13-diene (16) in all extracts. However, the presence of polar compounds, such as acids and alcohols, is an important common characteristic between the samples. In the amber extracts were detected regular abietanes - dehydroabietol (21), dehydroabietic acid (22) and abiet-8-en-18-oic acid (24) - and other polar abietanes 


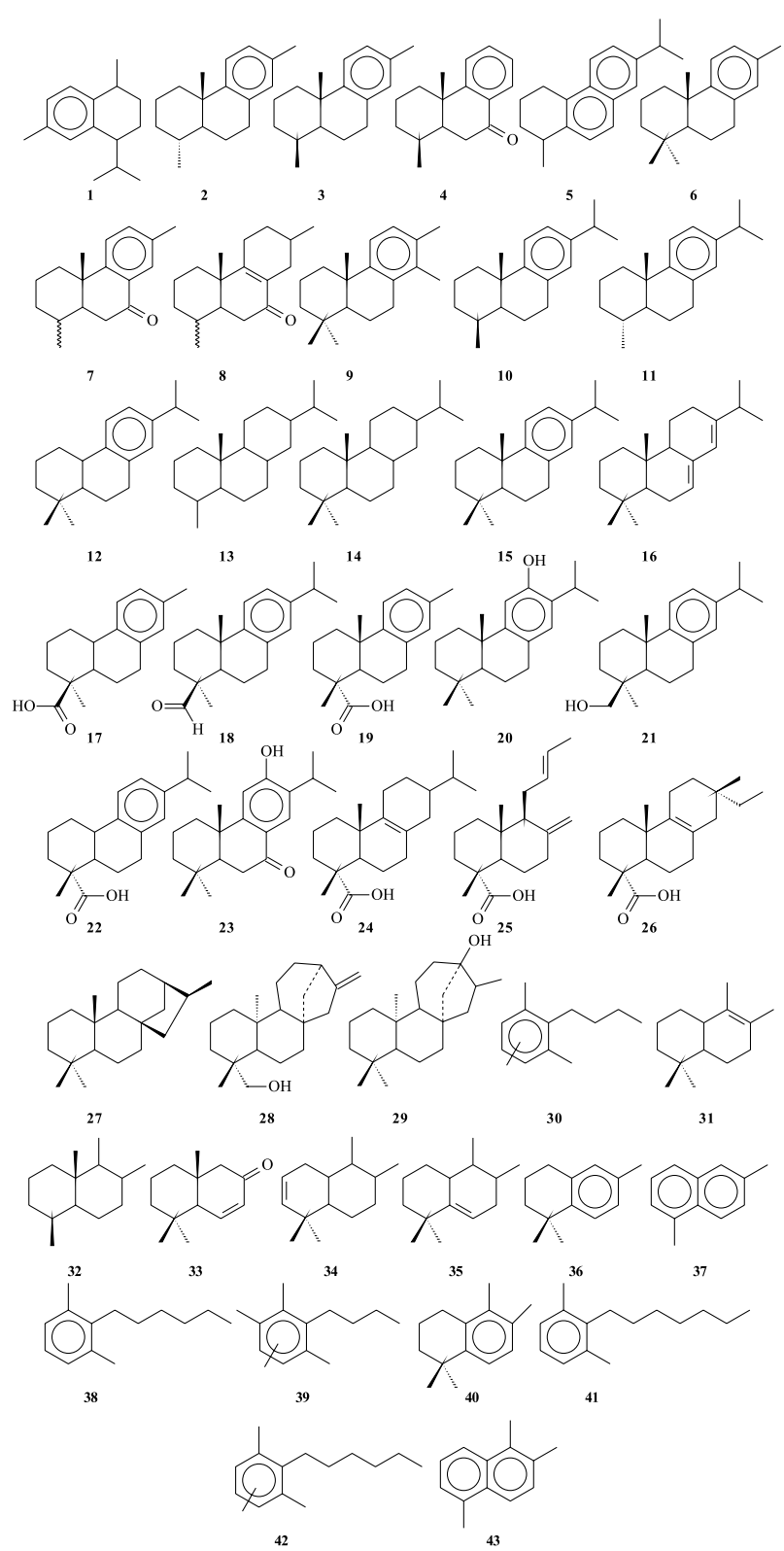

Figure 3. Chemical structures of identified compounds in Recôncavo ambers.

such as ferruginol (20) and sugiol (23, only in the sample 3$)$. Mass spectra from ferruginol and sugiol are given in the Supplementary Information. The samples are very similar showing GC-MS data almost identical. In the sample 3, it was observed high concentration of ferruginol and sugiol. Nevertheless, callitrisates, labdanes, pimaranes, isopimaranes, kauranes and phyllocladanes were not detected in the samples under study, even in derivatized extracts. Accordingly, the analyses of the three samples resulted in nearly identical compounds distribution, indicating that these ambers are all derived from the same, or similar, botanical source.

A small amount of alkylnaphthalenes and alkylhydronaphthalenes represented by ionene (36), dimethyl- naphthalene (37), tetramethylbutylbenzene (39) and trimethylnaphthalene $(\mathbf{4 3})$ were also detected in the extracts. Such compounds do not have chemotaxonomic value, being non-specific biomarkers ${ }^{17}$ and were not predominant. Volatile compounds of low molecular weight such as monoterpenoids or sesquiterpenoids were not observed in the extracts. In the same way, triterpenoids were not detected in any sample.

Some aspects regarding differences between the molecular data of the new Recôncavo ambers analyzed in this paper and the Recôncavo sample reported previously are described above. These aspects are probably related to botanical origins and chemical modifications of the resins during diagenesis. (i) Monoterpenes and sesquiterpenes were not detected. Monoterpenes are rapidly lost on exposure of samples to organic solvents in the preparation used for the biomarker analysis. The data reported in the previous study ${ }^{9}$ pointed to the detection of only one sesquiterpene, the calamenene (1) - a sesquiterpenoid of the cadinane class. Volatile components such as mono- and sesquiterpenes are gradually lost to the atmosphere when the resins are exudated. ${ }^{18}$ When these compounds are detected in amber they are occluded within the polymeric structure of the resins. (ii) The amber reported previously ${ }^{9}$ have a complex terpenoid composition, based on abietanes (mainly norabietanes), traces of labdanes and isopimaranes, and phyllocladanes and kauranes. The samples reported here are unlike, having a terpenoid composition constituted by regular abietanes, ferruginol (a phenolic abietane) and sugiol (a ketophenol), and lack of other diterpenoid classes. (iii) Several alkylbenzenes, alkylnaphthalenes and alkyltetralins were detected in the previous Recôncavo sample. ${ }^{9}$ In the current study, these compounds were not detected, except for small quantities of alkylnaphthalenes and alkylhydronaphthalenes.

Chemosystematic implications, possible botanical origins and the paleobotanical meaning of Recôncavo amber occurrences

The diterpenoid pattern of the fossil resins analyzed in this work have a comparatively easy interpretation in contrast with the molecular composition of Brazilian amber samples previously reported, particularly another amber sample from Recôncavo Basin. ${ }^{9}$ According Pereira et al. ${ }^{9}$ the composition of such sample is based on abietanes, for example 16,17-bisnorcallitrisic acid (17) and 16,17-bisnordehydroabietic acid (19), kauranes and phyllocladanes exemplified by $\alpha$-phyllocladane (27), kaur16-en-19-ol (28) and kauran-13-ol (29). This chemical composition pointed to Cupressaceae, Araucariaceae or 
Podocarpaceae families as the possible botanical origins of the sample. ${ }^{9}$

The regular abietanes detected in the new Recôncavo amber samples, such as acids, alcohols and hydrocarbons, are widely distributed in all conifer families (e.g., Araucariaceae, Podocarpaceae, Cupressaceae and Pinaceae) except Phyllocladaceae. Phenolic abietanes such as ferruginol, on the other hand, have been described in Cupressaceae and Podocarpaceae families, while resins from Pinaceae usually have predominant abietanoic acids. ${ }^{19}$ However, as already pointed out, Menór-Salvan and co-workers demonstrated that phenolic abietanes (particularly ferruginol) are Cheirolepidiaceae family biomarkers, ${ }^{7}$ an important new data with reference to chemotaxonomic aspects of coniferophytes. According to this work, the co-occurrence of ferruginol between BasqueCantabrian amber sample and fossil tissue of Frenelopsis suggests that this amber could be derived from Frenelopsis (Cheirolepidiaceae).

The no detection of callitrisates, kauranes and phyllocladanes in the extracts excludes a botanical origin linked to Cupressaceae or Araucariaceae. Therefore, it is conclusive that the presence of ferruginol in the samples is a strong indication of Podocarpaceae or Cheirolepidiaceae affinities. So, these two families are plausible to an association with the Brazilian ambers analyzed here.

Actually, many of the previous works that related phenolic abietanes only to Cupressaceae and Podocarpaceae must be reviewed, because it has been demonstrated that such compounds are also chemotaxonomic markers for Cheirolepidiaceae family. For example, abietanes such as ferruginol, hinokione and hinokiol were detected by Pereira and co-workers ${ }^{10}$ in other two Brazilian amber samples from Araripe Basin. However, considering the geochemical data presented by Menór-Salvan et al., ${ }^{7}$ the Cheirolepidiaceae family is another possible source for the cited Araripe ambers.

The sediments from Maracangalha Formation do not enclose plant macrofossils such as leaves or wood fossilized. Consequently, the presence of fossil resins in this stratum has an important significance to the knowledge about the Cretaceous paleoflora of the Recôncavo Basin in Brazil. Considering the chemical results found in the samples analyzed with well known chemotaxonomic markers, Podocarpaceae or Cheirolepidiaceae families are important botanical groups representatives of a resinous paleoflora in Maracangalha Formation. Moreover, researches about Brazilian Cretaceous amber have an important meaning to increase the knowledge concerning the chemical composition of fossil resins in Lower Cretaceous occurrences from the South Hemisphere. There are prior studies reporting that the amber occurrences from this period are associated to Araucariaceae or Cheirolepidiaceae sources, such as deposits in Spain, Africa and Middle Eastern. ${ }^{6,7,8,14}$ In this way, prior reports concerning ambers from South America, ${ }^{9,10,13}$ as well as the samples described here can enhance the understanding about the Cretaceous worldwide distribution of plant resins and the molecular composition of their fossil resins.

\section{Conclusions}

The extracts of three Cretaceous fossil resins from Recôncavo Basin (Maracangalha Formation, Brazil) contain terpenoids, alkylnaphthalenes and alkylhydronaphthalenes. Terpenoids are present as aromatic, saturated or unsaturated derivatives and also as polar compounds of abietane skeleton. Important diterpenoids were abietane, dehydroabietane, 1,2,3,4-tetrahydroretene, abieta-7,13-diene, abiet-8-en-18-oic acid, dehydroabietol, dehydroabietic acid, ferruginol and sugiol. On the other hand, mono-, sesqui- and triterpenoids were not identified, as well as diterpenoids from other structural classes such as kauranes, phyllocladanes, pimaranes, isopimaranes and labdanes. The terpenoid composition and the detection of ferruginol are consistent with conifers, mainly Podocarpaceae or Cheirolepidiaceae families. In addition, the presence of fossil resins in sediments from the Lower Cretaceous Maracangalha Formation allows information concerning the existence of a resinous paleoflora during the deposition of its sediments.

\section{Supplementary Information}

Supplementary data are available free of charge at http://jbcs.sbq.org.br as PDF file.

\section{Acknowledgments}

R. Pereira acknowledges the doctoral fellowship from CNPq. The authors thank Dr. Leonardo Borghi (IGEO/ UFRJ) for help in collecting samples. Dr. Tânia Lindner Dutra (UNISINOS) and Dr. Raphael Salles Ferreira Silva (LAGOA/UFRJ) for contributions and suggestions. Financial support from CAPES, CNPq, FAPERJ and FUJB is thankfully acknowledged. I. S. Carvalho, A. C. S. Fernandes and D. A. Azevedo are CNPq Senior research scholars.

\section{References}

1. Bray, P. S.; Anderson, K. B.; Science 2009, 326, 132.

2. Anderson, K. B.; Geochem. Trans. 2001, 3. doi: 10.1039/ b102650j. 
3. Langenheim, J. H.; Plant Resins: Chemistry, Evolution, Ecology and Ethnobotany, $1^{\text {st }}$ ed., Timber Press: Portland, 2003.

4. Martinez-Delclòs, X.; Briggs, D. E. G.; Peñalver, E.; Palaeogeogr., Palaeoclimat., Palaeoecol. 2004, 203, 19.

5. Bray, P. S.; Anderson, K. B.; Geochem. Trans. 2008, 9.

6. Alonso, J.; Arillo, A.; Barrón, E.; Corral, J. C.; Grimalt, J.; López, J. F.; López, R.; Martinez-Delclòs, X.; Ortuno, V.; Peñalver, E.; Trincão, P. R.; J. Paleontol. 2000, 74, 158.

7. Menor-Salván, C.; Najarro, M.; Velasco, F.; Rosales, I.; Tornos, F.; Simoneit, B. R. T.; Org. Geochem. 2010, 41, 1089.

8. Gomez, B.; Bamford, M.; Martínez-Delclòs, X.; C. R. Palevol. 2002, 1,83 .

9. Pereira, R.; Carvalho, I. S.; Simoneit, B. R. T.; Azevedo, D. A.; Org. Geochem. 2009, 40, 863.

10. Pereira, R.; Carvalho, I. S.; Fernandes, A. C. S.; Azevedo, D. A.; Quim. Nova 2009, 32, 1528.

11. Cruickshank, R. D.; Ko, K.; J. Asian Earth Sci. 2003, $21,441$.

12. Martinez-Delclòs, X.; Arillo, A.; Peñalver, E.; Barrón, E.; Soriano, C.; López, R.; Bernárdez, E.; Corral, C.; Ortuño, V. M.; C. R. Palevol. 2007, 6, 135.

13. Martill, D. M.; Robert, F. L.; Andrade, J. A. F. G; Cardoso, A. H.; Palaeontology 2005, 48, 1399.

14. Nissembaum, A.; Horowitz, A.; J. Afr. Earth Sci. 1992, 14, 295.

15. Silva, O. B.; Caixeta, J. M.; Milhomem, P. S.; Kosin, M. D.; Boletim de Geociências da Petrobras 2007, 15, 423.
16. Figueiredo, A. M. F.; Braga, J. A. E.; Zabalaga, J. C.; Oliveira, J. J.; Aguiar, G. A.; Silva, O. B.; Mato, L. F.; Daniel, L. M. F.; Magnavita, L. P.; Bruhn, C. H. L. In Interior Rift Basins; Lamdon S. M., ed., AAPG: Tulsa, 1994, Memoir 59, p. 157..

17. Otto, A.; Simoneit, B. R. T.; Wilde, V.; Kunzmann, L.; Püttmann, W.; Rev. Palaeobot. Palynol. 2002, 120, 203.

18. Cunningham, A.; Gay, A. D.; Oehlschlager, A. C.; Langenheim, J. H.; Phytochemistry 1983, 22, 965.

19. Otto, A.; Wilde, V.; Bot. Rev. 2001, 67, 141.

20. Simoneit, B. R. T.; Mazurek, M. A.; Atmos. Environ. 1982, 16, 2139.

21. Mills, J. S.; White, R.; Gough, L. J.; Chem. Geol. 1984, 47, 15.

22. Philp, R. P.; Fossil Fuel Biomarkers-Applications and Spectra, $1^{\text {st }}$ ed..; Elsevier: Amsterdam, 1985.

23. Czechowski, F.; Simoneit, B. R. T.; Sachanbinski, M.; Chojcan, J.; Wotowiec, S.; Appl. Geochem. 1996, 11, 811.

24. Cox, R. E.; Yamamoto, S.; Otto, A.; Simoneit, B. R. T.; Biochem. Syst. Ecol. 2007, 35, 342.

25. Otto, A.; Simoneit, B. R. T.; Org. Geochem. 2002, 33, 1241.

26. Gallegos, E. J.; Anal. Chem. 1973, 45, 1399.

Submitted: June 18, 2010

Published online: May 3, 2011 


\section{Chemotaxonomical Aspects of Lower Cretaceous Amber from Recôncavo Basin, Brazil}

Ricardo Pereira, ${ }^{*, a}$ Ismar S. Carvalho, ${ }^{b}$ Antonio Carlos S. Fernandes ${ }^{c}$ and Débora A. Azevedo*,a

anstituto de Química, Universidade Federal do Rio de Janeiro, 21941-909 Rio de Janeiro-RJ, Brazil

${ }^{b}$ Instituto de Geociências, Universidade Federal do Rio de Janeiro, 21910-200 Rio de Janeiro-RJ, Brazil

${ }^{c}$ Departamento de Geologia e Paleontologia, Museu Nacional, Universidade Federal do Rio de Janeiro, Quinta da Boa Vista, s/n, 20940-040 Rio de Janeiro-RJ, Brazil

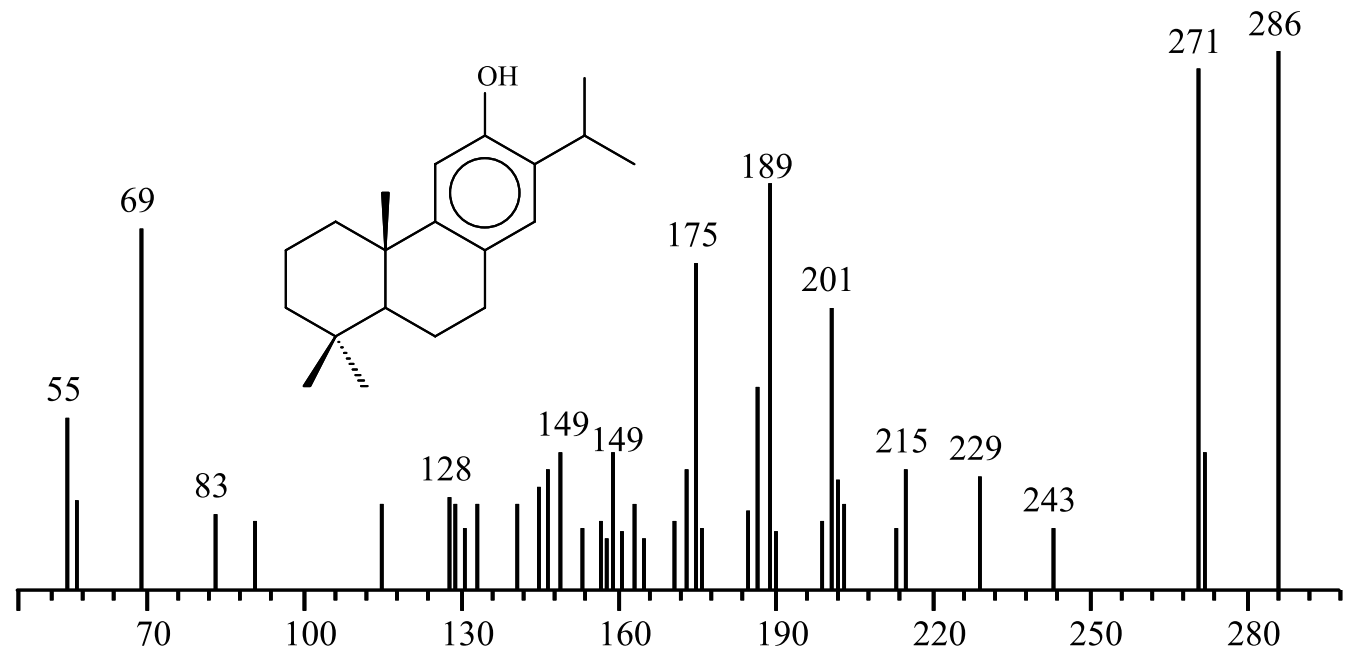

Figure S1. Mass spectrum of ferruginol.<smiles>CC(C)c1cc2c(cc1O)[C@@]1(C)CCCC(C)(C)C1CC2=O</smiles>

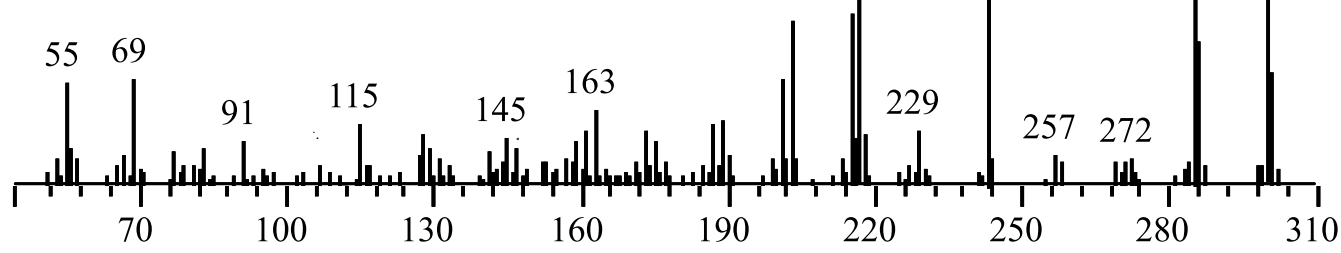

Figure S2. Mass spectrum of sugiol. 